\title{
Osmanlı Toplumunda Adli Psikiyatri Bağlamında Cinnet Kaynaklı Saldırılar (1831-1917)
}

\author{
Attacks Based on Insanity in the Context of Forensic Psychiatry in Ottoman Society (1831-1917)
}

\section{Gazi ÖZDEMIR ${ }^{1}$}

\begin{abstract}
$\ddot{O Z Z}$
Cinnet, insanların akıl sağlığının kısa süreli bozulması sonucunda ortaya çıkan ve çevresine yıkıcı zararları olan psikiyatrik bir durumdur. Ancak toplumsal hayatta özellikle basın yayın organlarında cinnet geçirmiş insanların yaralama veya ölümle sonuçlanan eylemleri üzücü olarak bültenlerde verilmektedir. Bu araştırmada Osmanlı toplumunda bir anlık öfke patlaması neticesinde aklın baştan gitmesiyle gerçekleşen günümüzde Amok ile karıştırılan cinnet saldırıları ele alındı. Osmanlı toplumunda yaşanan cinnet vakaları, adli psikiyatri boyutundan örnekleriyle incelendi. Türkiye Cumhuriyeti Cumhurbaşkanlığı Devlet Arşivleri Başkanlığı Osmanlı Arşivi Belge Tarama Sistemi (BETSİS) üzerinde yapılan taramada 288 cinnet vakası tespit edildi. Bunlar içinde araştırma kapsamına giren ve cinnet geçiren kişilerce yaralama veya ölüm ile sonuçlanan 1831-1917 tarihleri arasında yaşanmış 47 vaka araştırmaya dâhil edildi. Bunlara ilaveten Avni Mahmut'un Muhtasar Emrâz-1 Akliye isimli eserinde yer alan iki cinnet vakası da eklenerek araştırma evreni oluşturuldu. Bu araştırmada nitel araştırma yöntemi ve retrospektif/regresif tekniği kullanıldı. Veriler, içerik analizi ile değerlendirildi. Sayısallaştırılan verilerin betimsel analizi Pivot Table'da yapıldı. Sonuç olarak Osmanlı Devleti'nde cinnet geçiren kişilerin sağlık kontrollerinin kişi hakları ile adli ve idari düzen adına dikkate alındığı, bu kişilerin adliye, emniyet ve diğer kuruluşlarca darüşşifaya, bimarhaneye ve Tibbiye Mektebi'ne sevk edildikleri görüldü. $\mathrm{Bu}$ birimlerde uzman hekimler tarafından akıl sağlıklarının yerinde olup olmadığı ile ilgili yürürlükte olan mevzuatlara göre gözetim, tanı ve tedavi süreçleriyle ilgili işlemlerin gerçekleştiği, maznun hakkında cezai ehliyetiyle ilgili kararları raporlayarak yetkili makamlara gönderdikleri görüldü. İncelenen vakalar içinde cinnet hadiselerinin \%100'ünü erkeklerin gerçekleştirdiği ve toplamda 49 cinnet saldırısından 80 kişinin zarar gördüğü tespit edildi.
\end{abstract}

Anahtar Kelimeler: Osmanlı toplumu, Cinnet, Amok, Cinayet, Emrâz, akıl

\begin{abstract}
In today's psychiatry literature, the phenomenon of insanity is either incompletely defined or not defined at all. However, in social life, especially in the media, the actions that result in injury or death of people who have brought insanity continue to exist as a sad state of affairs. In this research, the insanity attacks that occurred as a result of a sudden outburst of anger in Ottoman society were discussed. The cases of insanity in the Ottoman society were examined with examples from the dimension of forensic psychiatry. In the scan made on the Ottoman Archive Document Scanning System (BETSIS) of the Presidency of the Republic of Turkey State Archives, 288 insanity cases were detected. Among these, 47 cases between 1831-1917, which were included in the research and resulted in injury or death by people who went insane, were included in the study. In addition to these, the research universe was created by adding two cases of insanity in Avni Mahmud's book titled Muhtasar Emrâz-1 Akliye. Qualitative research method and retrospective/regressive technique were used in this study. The data were evaluated by content analysis. Descriptive analysis of the digitized data was done in Pivot Table. As a result, it was seen that the health checks of the people who went insane in the Ottoman State were taken into account in the name of personal rights and the judicial and administrative order, and these people were sent to the hospital, hospital and Medicine School by the courthouse, police and other institutions. It is understood that in these units, the procedures related to the surveillance, diagnosis and treatment processes are carried out by the specialist physicians in accordance with the legislation in force regarding whether their mental health is in place, and they report the decisions regarding the criminal capacity of the accused and send them to the competent authorities. Among the cases examined, it was determined that $100 \%$ of the insanity incidents were carried out by men and that 80 people were harmed in total from 49 insanity attacks.
\end{abstract}

Keywords: Ottoman society, Insanity, Amok, Murder, Mental illness

\footnotetext{
${ }^{1}$ Dr. Öğr. Üyesi, Gazi ÖZDEMİR, Tarih, Bayburt Üniversitesi İnsan ve Toplum Bilimleri Fakültesi Tarih Bölümü, e-posta, gaziozdemir@bayburt.edu.tr, ORCID: 0000-0003-2306-5280 


\section{GİRIŞ}

Osmanlı tıp terminolojisi içinde cinnet (folie), akıl ve ruh hastalıklarının genel adı olmakla birlikte hastalıkların özel ismi olarak da adlandirılmaktaydı. Bunun yanında cinnet hastalığ1 için illet-i cünûn, tecennün, eser-i cünûn, muhtell-i dimağ, muhtell-i şuûr, münhâl-i dimağ, münhâl-i akl, eser-i heft gibi isimlendirmeler de kullanılmaktaydı. ${ }^{1,2}$

Akıl hastalıkları İslam hukukunda ataha (budalalık) ve cünûn (vahşi saldırganlık gösteren) şeklinde kategorize edilmişti. Osmanlı tabâbet-i ruhiyye ve akliyye hekimlerinin (psikiyatr) de akıl hastalıklarını kendi bilgileri dâhilinde kategorize etme girişiminde bulundukları bilinmektedir. $\mathrm{Bu}$ isimlendirme işlemlerini gerçekleştirdikleri süreçte, Osmanlı tıbbını Türkçeleştirme ve tıp alanında yenilikleri yakalama adına Fransız hekimlerinin yazdığı eserlerden yararlandıkları ve akıl hastalıklarında bu eserleri referans alarak hastane kayitlarından hareketle belirli bir terminolojiyi oluşturmak istedikleri anlaşılmaktadır. ${ }^{3,4} \mathrm{Bu}$ hastalıklardan bazıları arasında Mâlihulyâ (melankoli), malihulya-yı hadd, malihulya-yı tahtel-hadd, Maniya, manya-yı hadd (açık olarak belli olan, şiddetli mani), maniya-yı vaz' ve maniya-y1 tahtel-had (hipomani), ateh (demans), cinnet-i katl sayılabilir. ${ }^{2,5-7}$

Osmanlı Devleti'nde akıl ve ruh hastalarıyla ilgili müşahade, muayene ve tedavi (gözlem, tanı ve sağaltım) süreçlerinde dönemsel farklılıklar görülmektedir. $\mathrm{Bu}$ değişimi, Manisa Hafsa Sultan Darüşşifası, Toptaşı Bimarhanesi, Osmanlı Devleti'nde Deliliğin Tibbileştirilmesi ve 1876 Bimarhaneler Nizamnamesi yayınlarından takip etmek mümkündür. ${ }^{8-10}$

Osmanlı Devleti'ndeki adlî psikiyatrinin kuruluş süreci ve işleyişiyle ilgili Adlî Psikiyatri: Dr. Luigi Mongeri'nin Raporları, Tespitleri ve Bir Vaka Örneği ile Adli psikiyatride bilirkişiliğin incelendiği Adli Doktorlar, Ruh Doktorları ve Şeyhler: Kummerau Olayı (1880) ve Bilirkişilik Meselesi Kummera araştırmalarında yer almaktadır. ${ }^{11,12}$
İnsanları derinden üzen ve vicdanları yaralayan cinnet rahatsızlığı ile ilgili modern çağ alanyazınında çok fazla yayın olmamakla birlikte Turla ve Böke, Nedir Bu "Cinnet" Dedikleri? makalesiyle konuya 1 şık tutmayı amaçlamışlardır. Onlara göre Amerikan Psikiyatri Birliği tarafından yayımlanan ve modern psikiyatr için referans kaynak olan DSM 5 Tanı Ölçütleri Başvuru Elkitabi ${ }^{13}$ içinde cinnet rahatsızlığının yer almaması vaka kayıtlarının dağınık şekilde tutulmasından kaynaklanmaktadır. Bahsi geçen yazarlar, cinnet saldırılarını amok tarzı saldırı olarak tanımlamaktadırlar. ${ }^{14}$

Amok, 1770 yılında Malay kabilesini ziyareti sırasında hazırladığı raporla Kaptan Cook tarafindan alanyazına kazandirıldı. Malayca mengamok kelimesinden türetilen amok ya da amok koşusu vakası, cinnet geçiren bir kişinin aklını yitirmişçesine ağzından köpükler çıkararak koşturması, birden fazla insanı öldürmek için sağa-sola saldırıp etrafindaki canlılara zarar vermesi veya onları öldürmesi eylemine verilen, ilk başlarda kültürel bir hastalık olarak tanımland $1 .{ }^{15} \quad$ Amok, Cook'un çalışmalarından sonra ilk olarak 1849 civarında psikiyatrik bir durum olarak sinıflandirıldi.

Turla ve Böke, cinneti, amok hastalığ 1 olarak tanımakla birlikte uyku bozuklukları, epilepsi, aralıklı patlayıcı bozukluk, borderline, şizofren ve dissosiyatif bozukluklar gibi rahatsızlıkların cinnetin gerekçeleri olabileceğini ileri sürmektedirler. Bununla birlikte cinnetin ruhsal bir rahatsızlık olduğunu ve tanısının hala tam olarak konulmadığını da belirtmektedirler. ${ }^{14}$ Turla ve Böke'nin bu görüşleri Osmanlı tarihi kaynaklarına ve belgelerine dayandırmadan yalnızca batılı kaynakları referans alarak açıklandığı için tarihi bakımdan eksiktir. $\mathrm{Bu}$ sebeple Osmanlı toplumu, hukuku ve tıbbinda cinnet kavramını, kendi kaynağından ortaya koymak gerekmektedir. ${ }^{3,40.1} \mathrm{Bu}$ çalışmada Osmanlı'da yaşanan cinnet saldırılarının tek başına amok tarzı saldırılar ile 
açıklanamayacağı ortaya konulmaya çalışılacaktır.

Her geçen gün gelişen teknoloji, hastalıkların tanılanmasından suça dair delillerin ortaya konulmasina kadar her alanda hizmet sunmaktadır. Bu hizmetler hekimlere, kolluk kuvvetlerine ve yargıya önemli kazanımlar sunmaktadır. ${ }^{16}$ Lakin bu teknoloji çağında bile cinnet hadiselerine bağlı saldırıların ve cinayetlerin önüne tamamen geçilememektedir. Ayrıca Osmanlı toplumunda yaşanan cinnet hadiseleri sonuçları itibariyle insan yaralama ve öldürme şeklinde gerçekleştiğinden öyle kolay anlaşılacak bir hadise gibi de görünmemektedir.

$\mathrm{Bu}$ makalede Osmanlı toplumunda cinnetin ne olduğu, bir insanın cinnet geçirip geçirmediğine kimin karar verdiği, ölçütlerinin neler olduğu, cinnet geçirenlerin hukuki durumları, cinnetin adli psikiyatrik boyutları, cinnet saldırılarının gerçekleşmesinde hangi hastalıkların etkili olduğu, Osmanlı toplumundaki cinnet olayları ve dağılımlarının nasıl olduğu ve cinnet geçirenlere ne yapıldığı incelenecektir:

\section{MATERYAL VE METOT}

Araştırma sorularının cevaplanmasında ve teorik çerçevenin çizilmesinde nitel araştırma yöntemleri ile retrospektif/ regresif kullanıldı. T.C. Cumhurbaşkanlığı Devlet Arşivleri Başkanlığı Osmanlı Arşivi (BOA) Belge Tarama Sisteminde (BETSİS) açık erişime sunulan ve cinnet kavramının yer aldığı 1831-1917 yılları arasında yaşanan 288 vaka içindeki yaralama veya ölüm ile sonuçlanan 47 cinnet vakasının tamamı araştırma evreni olarak seçildi. Buna ilaveten yine aynı zaman aralığında yer alan Avni Mahmut'un Muhtasar Emrâz-1 Akliye isimli eserinde bulunan 2 cinnet vakasi da bu evrene eklendi. Veriler, içerik analizi ile değerlendirildi. Sayısallaştırılan verilerin betimsel analizinde Pivot Table kullanıldı. Analizlerde vakaların tamamı kullanılırken olaylarla ilgili hususlarda amaçlı örneklem tercih edildi.

$\mathrm{Bu}$ araştırmadaki en önemli kısıtlılığı güncel vakalarda olduğu gibi tüm yönleriyle tutulmuş olan psikiyatri dosyalarına ulaşılamaması oluşturdu. Fakat devrin psikiyatrları tarafından tutulan ve paylaşılan ve de işlem yönünden ilişki kurulması mümkün olan vakalardan yararlanmak suretiyle sorun aşılmaya çalışıldı. Cinnet olgusunu ve cinnetin etkilerini yazma aşamasında anakronizme düşmemeye gayret edildi. Bu sebeple kavramların kullanımında konunun daha iyi anlaşılması için arasözlerden veya parantezlerden yararlanıldı. Son olarak cinnet ile ilgili hastalı kavramlarında yazımda sesli harflerin bulunmaması kavramların okunması sırasında güçlükler oluşturdu. Bir diğer sinırlılık da Dergi'nin yayın ilkeleri içinde yer alan 40 kaynak sinırıdır. Bu sebeple bazı kaynaklar makalede gösterilemedi ve arşiv belgeleri farklı bir kategori ile sunulmak durumunda kalındi.

\section{BULGULAR VE TARTIŞMA}

\section{Cinnet, Gözlem, Tanı ve Sağaltım Kurumları}

Osmanlı tıbbında vücuttaki organların hastalanması gibi aklın da hastalandığ 1 ve diğer hastalıklar gibi belirtiler verdiği kabul edilmekteydi. ${ }^{17}$ Akıl hastalıkları dönemin bilimsel imkânları ölçüsünde uzmanlar tarafından tanımlanmaya çalışılmaktaydı.
Cinnet (folie) kavramı, Osmanlı hukuku ve tıp kurumlarında genel bir ifade şeklinde kullanılmakla birlikte aklın bir an baştan gitmesiyle gerçekleştirilen şiddet eylemlerini içine dâhil etmekteydi. Öyle ki mecnûn ve mecanîn kavramlarının akıl hastalarını tanımlamak için de kullanılması cinnet kavramının kullanım alanının geniş olduğuna işaret etmektedir. ${ }^{5,7,18,19,40.2}$ 
Mecnunlar, gerçeği değerlendirme melekesi bozulmuş, sanrılar gören ve/veya davranış bozuklukları bulunan hastalardı. $\mathrm{Bu}$ hastalar, toplum tarafindan deli olarak tanımlanan sürekli akıl hastaları (cünn-i mutbık) ile genel sağlı̆̆ının yerinde olmasına rağmen çeşitli sebeplerle geçici akıl sağlığını kaybeden (cünn-i gayr-1 mutbık) kimselerden oluşuyordu. Bir yıldan fazla akıl hastalığı yaşayanlar sürekli akıl hastası olarak kabul edilirken eylemi gerçekleştirdiği sırada geçici olarak aklını, şuurunu ve iradesini kaybeden kişiler, sadece nöbetin geldiği anda yetkili otoritenin vereceği raporla hasta kabul edilmekteydi. ${ }^{20,21}$

Cinnet anında gerçekleşen saldırılar, kişinin tanıdığ 1 veya tanımadığ 1 kişiye olabildiği gibi, ilişki düzeyinin yönüne bağl1 kalmaksızın aniden veya belirli bir süreç dâhilinde, planlı veya plansız bir biçimde gerçekleşebilmekteydi. Bu saldırı sonucunda saldırıya uğrayan birey ya da bireyler yaralanmakta veya öldürülmektedirler., ${ }^{41,40.3}$ Yaşanan olaylar sonucunda suç, suçlu, mağdur, yakın çevre, kamu düzeni ile ilgili hususlar gündeme gelmektedir. Bu problem gerek klasik dönemde gerekse Osmanlı modernleşmesi döneminde idari ve adli makamların yönetim organizasyonlarınca belli uygulamalara tabi tutularak çözüme kavuşturulmaya çalışılmaktaydı. Osmanlı Modernleşme döneminde yenileşen kurum anlayışları ve gelişen teknik imkânlar kurumsal anlamda yeni uygulamaların hayata geçirilmesine olanak verdi. Tip alanında atılan adımlarla adli tıp ve onun alt birimi olan adli psikiyatri ile adli kriminoloji kurumsal anlamda hizmet vermeye başladı. $\mathrm{Bu}$ kurumların vakaların incelenmesinde bilimsel yöntemleri kullanması, adlî olayların olay takip süreçleri, laboratuvar ve karar aşamalarında adaletin tesisinde ciddi katkılar sundu. ${ }^{11,23,24}$

Hukuk kuralları, hâkimlere yargılama süresince hem yol göstermekte hem de karar verme aşamasında bağlayıcı hükümler içermekteydi. Osmanlı hukuk sisteminin temeli şer'i ve örfi kıstaslara bağlı olarak hazırlanmış olmasına rağmen modernleşme süreci içinde ileri hukuk sistemlerinden resepsiyon yoluyla yarg1 hükümleri, dönemsel olarak farklı şekilde işletildi. Burada değişmeyen husus, kişilerin mükellefiyeti ve sorumlulukları bağlamında akıl ve iradesiyle ortaya koyduğu davranışın belirleyici rolüydü. Bireyin eylemi gerçekleştirmeyi akıl ve irade sahibi olarak istemesi cezai ehliyet için bağlayıcı hükümdü. $\mathrm{Bu}$ sebeple Osmanlı adalet kurumu, eylemi gerçekleştiren kişinin eylemi gerçekleştirdiği sırada akıl ve iradesinin olup olmadığının tespitini gündeme getirdi. $\mathrm{Bu}$ sebeple dönemin yürürlükteki uygulama esasları doğrultusunda bu işlem yetkili kurumlarca gerçekleştirilmekteydi. 8,18,19,25,26

Osmanlı Devleti'nde akıl hastalığı ile ilgili gözlem, tanı ve sağaltım süreçleri darüşşifa, bimarhane ve sonrasında hastaneler vasıtasıyla gerçekleştirilmekteydi. Selçuklular Dönemi'nden itibaren Anadolu'da kurulan ve vakıf sistemiyle hizmet veren bu kurumlara Osmanlilar döneminde padişahlar, valide sultanlar ve hasekiler tarafindan yenileri eklendi. ${ }^{27}$ İstanbul'da Fatih Darüşşifası (1470), Haseki Sultan Darüşşifası (1529), Süleymaniye Darüşşifası (1555), Valide-i Atik Darüşşifası (Toptaş1 Bimârhânesi) (1581) ve Sultan Ahmet Darüşşifası (1617), Edirne Darüşşifası ve Manisa Darüşşifası bu kurumlar arasında yer almaktayd.$^{5,28}$

Osmanlı darüşşifalarında akıl ve ruh sağlığı yerinde olmayan ve çoğunluğunu sakin tabiatlıların oluşturduğu hastalara gözetim, tanı ve sağaltım hizmetleri verilmekteydi. Bu hastalara vakfiye şartlarına uygun olarak haftanın belirli günlerinde sağaltımları için güzel kokulu çiçeklerin bulunduğu havuzlu bahçede zengin çalg1 aletleri ile müzik seansları düzenlenmekteydi. ${ }^{6}$ Bu hizmetler, vakıfların statik yapısı, yöneticilerin ve çalışanların ilgisizlikleri ve savaşlarda toprak kayıpları ile vakif gelirlerinin gasp edilmesi gibi nedenlerle fonksiyonlarını yerine getiremez oldular. Bunun sonucunda zamanla bu yerler yalnızca hastaların kontrol altında tutulduğu, yaşanamayacak derecede sağlıssız ve insan 
onuruna yakışmayan yerler haline dönüştüler. ${ }^{6,29,40.4}$

Sağlık hizmetlerinin iyileştirilmesi için 1847 yılında Bezm-i Âlem Vakıf Gurebâ Hastanesi kuruldu. Bu hastanenin açılmasıyla birlikte akıl hastaları ile genel hastaların sağaltım kurumları birbirinden ayrıldı ve akıl hastaları Süleymaniye Bimarhanesi'ne yönlendirildi. Artı bimarhanelertımarhaneler- akıl hastalarının sağaltımlarının gerçekleştirildiği kurumlar oldu. $\mathrm{Bu}$ kurumları modernleştirme faaliyetleri 19. yüzyılda Sultan II. Mahmud tarafindan 14 Mart 1827 tarihinde Tıphâne-i Âmirenin açılmasıyla başladı. $\mathrm{Bu}$ adımdan sonra yapisal ve kurumsal anlamda hizmet standartlarının belirlenmesi için yasal düzenlemelere geçildi. $\mathrm{Bu}$ iş için görevlendirilen Luigi Mongeri, 30 Haziran 1838 tarihinde yürürlüğe giren Fransız Akıl Hastaları Kanunu'nu referans alarak nizâmnâme taslağı hazırladı. Zaptiye Nezareti'ne sunulan bu taslak üzerinde bazı değişiklikler yapıldıktan sonra 15 Mart 1876 tarihli padişah iradesi ile yürürlüğe girdi. Böylece Osmanlı sınırları içindeki bütün darüşşifa, bimarhane ve hastanelerin işleyişi ile ilgili birlik sağlanmasına yönelik uygulama hayata geçirildi. Bundan sonraki süreçte uygulamada yaşanan bazı aksaklar olmasına rağmen adlî, idarî veya diğer yetkili makamlar tarafından akıl hastalığı olanlar ile akıl hastalığ 1 şüphesi olanlar hakkında kurallar getirildi. Devlet yetkilileri tarafından veya çevre gözetim, tanı ve sağaltımlar için bimarhanelere gönderilme, kayıt, kabul ve diğer işlemlere ait uygulama esasları belirlendi. Böylece de uygulamada birlik sağlanmış oldu. ${ }^{30,40.5}$ Konuyla ilgili çıkan nizâmnâme kuralları aynı zamanda gayrimüslimlere ait Yedikule'deki Balıklı Rum Hastanesi, Ermeni Cemaati'ne ait yine Yedikule'deki Surp Pırgiç Hastanesi, Katolik Ermeniler'e ait Surp Agop Hastanesi ve Fransiz La Paix Hastanesi'ni de bağlamaktaydı. ${ }^{8,29}$

\section{Osmanlı'da Yargı ile Adlî Psikiyatri İlişskisi}

Osmanlı toplumunda yaşanan cinnet hadiseleri yaralama ve öldürme eylemleriyle sonuçlanması durumunda mesele adli makamlara yansıyabilmekteydi. $\mathrm{Bu}$ mahkemelerde görev yapan hâkimler, davaları ilk dönemlerde şer'i ve örfi hukuk ile kanunlarıyla sonuçlandırırken Tanzimat ile birlikte batıdan uyarlanan hukuk kurallarıyla karara bağladılar. Hâkimler adil yargılama gerçekleştirebilmek için her dönemde ihtiyaç durumunda alan uzmanlarından yani bilirkişilerden destek aldilar. ${ }^{16,31}$

Özellikle şüpheli ölümlerde olayın aydınlığa kavuşma için keşif yapılması önem arz ediyordu. Tip Kanunun yayımlanmasiyla birlikte ülke genelinde bir mahalde veya sokakta aniden bir ölüm gerçekleşirse olay ile ilgili adli tabip tarafindan keşif ve muayene istenirdi. Bu süreç tamamlanmadan defin işlemine izin verilmezdi.

Keşif ve adli muayene sırasında görevli doktor, cesette öldürücü darbe veya şüpheli bir durum olup olmadığını incelerdi. Şayet şüpheli bir durum varsa feth-i meyyit (otopsi) talep ederdi. ${ }^{32} \mathrm{Bu}$ süreçte kişinin ölüm sebebi, kimliği, madde kullanıp kullanmadığı araştırılırdı. Bıraktığı yazılı belge, olayda kullanılan saldırı aleti incelenir, olay yeri incelemesi yapilirdi.

$\mathrm{Bu}$ işlemin yanında bilirkişiler, mahkemeye yargılama sürecinde şüpheliler ile ilgili yetkili organların talepleri doğrultusunda farklı çalışmalar da yürütürdü. Bunlar arasında suçun, suçlunun veya kabahatin ortaya çıkmasında, suç araçlarının araştırılmasında ve tanımlanmasında; gerçekleşen suç eylemiyle kişinin yaşının, cinsiyetinin ve cezai sorumluluğunun olup olmadığını incelerlerdi. ${ }^{24,40.6}$ Böylece hâkimler hükümlerini bilirkişilerin keşif ve incelemelerdeki elde ettikleri delillerle ve şahitlerin ortaya koyduğu bilgilerle kanunlar ölçüsünde vicdanlarıyla hükmü açıklayabilirlerdi. Zira adalet, bilimsel temellere ve objektif delillere dayandığ oranda doğru ve isabetli olabilmektedir. 
Medeniyetler, işlenen suça karşıllk bir ceza verilmesinin gereklilik ve zorunluluk olduğunu kabul etmektedir. Bununla birlikte ceza yöntemleri üzerinde farklı uygulamalar hayata geçirmektedir., 20,21,33 $\mathrm{Bu}$ bakımdan genel olarak çocuklar ve akıl sağlığı yerinde olmayanların yaptıkları hareketten doğacak zararları ve tehlikeleri düşünemedikleri ve idrak edemedikleri kabul edilmektedir. Özellikle akıl hastalığı bulunan kişilere kasıt, kusur ve fena niyet atfedilememektedir. Ak1l hastalarının, patalojik bir düşünce içinde yanlış ve hatalı fikirlere dayanarak bir suçu tasarlamış ve tamamlamış olmaları mümkündür. Fakat bu tasarıda düşünceler gerçeklere dayanmadığ unsuru olan amaç ve saik oluşturmaz. Bu kapsamda kişiye yaptırım uygulanabilmesi için adli psikiyatrın kişinin akıl sağlığıyla ilgili rapor düzenlemesine ihtiyaç duyulmaktadır. ${ }^{11}$ Adlî yargılamada adalet açısından kişinin akıl hastası olup olmadığının tespiti, hastalığın hastanın algılama ve irade yeteneği üzerinde ne kadar etkili olduğunu, davranışlarını ne surette yönlendirdiğini belirlemek psikiyatrların uzmanlık alanıydı.

Uzman hekimler yaralama veya ölümle sonuçlanan olayda failin olay anında ve genel yaşamında elde edilen bulgularla akıl sağlığının durumunu tespit ederlerdi. Böylece şüphelinin olay anında algılama veya irade yeteneğini, hastalığın kişinin eylemi gerçekleştirmedeki yeteneklerini ne ölçüde etkilediğini incelemeler ve süreç tamamladıktan sonra hazırladıkları raporları hüküm vermeksizin adli makamlara gönderirlerdi. ${ }^{5}$

\section{Adli Psikiyatrinin Sahası ve Fonksiyonu}

Osmanlı Devleti'nde adli veya idari makamlar tarafından yürütülmekte olan soruşturma veya dava sırasında şüpheli olan kişinin eylemi cinnet halinde gerçekleştirdiği şüphesi hâsıl olursa veya şüphelinin kendisi ya da vekili tarafindan cinnet halinde eylemi gerçekleştirdiği iddia edilirse şüpheli sağlık kontrol için ilgili kurumlara yönlendirilirdi. $\mathrm{Bu}$ kurumlar ilk dönemlerde müftülükler idi. Hâkimler müftülerden şüpheliyi değerlendirmesini cezai ehliyetinin olup olmadığı ile ilgili fetva vermesini ister, sağlığı yerinde ise şüpheli hakkında hükmünü açıklardı. Süreç içinde müftülüklerin yanına darüşşifa, bimarhane ve hastane kurumlar1 eklendi. ${ }^{4,5,7,34,35,40.7}$

Yeni kurumların eklenmesinde sonra uygulamalarda da bazı değişiklikler oldu. Buna göre bireyler, yaralama ya da cinayet gibi bir suça karıştıklarında, kolluk kuvvetleri, müdde-i umumilik (savcıllk, sorgu hâkimi) veya mahkeme kararıyla akli yönden sağlık kontrolünden geçirilirlerdi. Bu süreçte birey hemen bimarhaneye yönlendirilmez, akıl sağlığıyla ilgili ön inceleme yapılırdı. Zira sağliklı bireylerin direkt bimarhaneye gönderilmeleri ve akıl sağlığı yerinde olmayanlarla bir arada bulundurulması hukuki değildi. Bunun için şüpheli kişi ileri medeniyetlerde olduğu gibi gözlem ve tanı (müşahade ve muayene) için ilk önce zaptiye memurları gözetiminde belirli bir süre nezarethanede tutulurdu. İstanbul dışından gönderilen mecanîn şüphelileri, belediye ve zabıta idarelerince ilk önce müşahadehanelere sevk edilir, sevk edilenlerden suçsuz olanlar burada bir müddet gözetim altında tutulur, bu süre zarfinda cinnetleri ortaya çımaz veya tekrarlamazsa tahliye edilirlerdi. Rahatsızlığ tekrarlayanlar ise bir ay sağaltım için bimarhaneye sevk edilirlerdi. ${ }^{40.8}$

Bazen resmi kararların aksine uygulamalarda gerçekleşebiliyordu. Nitekim İstanbul dışından gönderilen şüpheliler, müşahadehane yerine doğrudan bimarhanelere gönderiliyordu. ${ }^{40.9} \mathrm{Bu}$ tür işlemler bimarhane hekimleri tarafından uygun görülmüyor ve bu işi yapan Bab-1 Ali, Emniyet-i Umumî Müdürlüğü ve Şehremanet-i Aliyesi ile İstanbul Vilayeti uyarıliyordu. $\mathrm{Bu}$ problemin ve kapasite sorununun aşılması için Haseki Bimarhanesi geçici süreliğine müşahadehane olarak tahsis edildi. ${ }^{6}$

\section{Akıl Hastalarının Sorgulama ve Kontrol Yöntemleri}

Bireylerin muayene süreci ilgili gözlem ve tanılama işlemleri Tip Kanunu ${ }^{32}$, 
Bimârhânelere Dair Nizâmnâme ${ }^{30}$, Zabtiye Nezaretinin 27 Ocak 1895 [15 Kanun-1 Sani 1310] tarihinde yürürlüğe giren tamim ve Usul-i Muayene ve İsticvâb-1 Mecânin (Ak1l Hastalarının Sorgulama ve Kontrol Yöntemleri) doğrultusunda yürütüldü. $., 7,40.10$

Bimarhaneye alınacak kişilerin elinde senet ya da evrak bulunmadıç̧a bimarhane müdürü tarafından kuruma kabul edilmemekteydi. $\mathrm{Bu}$ belgede isim, şöhret, sanat, memleket ve ikametgâh bilgileri ile mecnun ile yakınlığı kayıt altına alındı. Belgelerin düzenlenmesinde Dersaadet'te Nezaret Zabtiyesi, taşralarda ise yerel yöneticiler yetkiliydi. Şayet dilekçeler kabul edilecek olursa şahısların tahkikinin yapılması ve ikamet ettiği mahalle imamı ve muhtarı tarafından mühürlü bir ilmühaber göndermeleri gerekliydi. ${ }^{30} \mathrm{Bu}$ belgede bireyin/ marizin cinnet hadisesi yaşanana kadar geçen hayatıyla ilgili bilgiler ile cinnet anında yaşadığı bilgiler rapor halinde yazılmas1 gerekliydi. Bu rapor ile doktorlar bireyin muayene, teşhis ve sağaltım süreçlerine başlamadan önce annesi, babası, büyükannesi, büyükbabası, erkek ve k1z kardeşleri ile çocukları ve diğer akrabalarının herhangi birinde emrâz-1 akliye ve asabiye, afet-i dimağ, madde bağımlılığ ve intihar gibi vakalar olup olmadığ hakkında bilgi sahibi olacaklard1. 5,7,40.11

$\mathrm{Bu}$ bilgilerden hareketle psikiyatrılar, ak1l ve ruh hastalıklarının tanı ve sağaltım süreçlerinde aile geçmişi, biyolojik rahatsızlıkları, psikolojik özellikleri ve fiziksel özelliklerinin tanımlanması uzman hekimlere gözlem, tanı ve kontrol aşamasında önemli ipuçları elde etmiş olacaklard1. $5,7,40.12$

Bimarhane'ye girişi yapılan bireyler hakkında bilirkişilik hizmeti verebilmek için üç aşamalı bir süreç takip edilmekteydi. Bunlar tahkikât, isticvâb ve istintâk, müşahadat-1 müstakımıyye ve müteakıbiyye aşamalarıydı.

Müşahede ve muayene için gelen bireyler hakkında biyolojik, fiziksel ve psikolojik özellikleri ve bilgileri ilk kuruma geldiğinde inceleme yapılarak suç geçmişi ve gözlem formu doldurulurdu. Bunlar içinde kuruma girişi yapılan bireyin zekâsının derecesi, huy ve karakter özellikleri, hisleri ve eğilimleri, mizacının sinirli ya da durgun oluşu, yaşı, ergen olup olmadığı, bu sürecin nasıl yaşadığı ve etkileri sorgulanırdı. Bunlara ilaveten sevdiği olup olmadığı ve bağımlılık yapan madde kullanıp kullanmadığ irdelenirdi. Çevresinde yaşadıklarıyla bazı günlerde problem yaşayıp yaşamadı ğ bir felaket ve sıra dışı bir sevinç yaşayıp yaşamadığı öğrenilirdi. Şayet cinnet geçiren kişinin yazışmaları varsa bu yazılar da incelenirdi. Birey hakkında bilgiler alındıktan sonra tanı için isticvâb (soru cevap) aşamasına geçilirdi.

Soru cevap kısmında uzman hekimleri bekleyen tehlikeler şöyleydi: cinnet-i menkûre (cinneti inkâr etme) ve cinnet-i mektûme (cinneti gizleme) ile cinnet-i mukarra (gerçeği söyleme) ve cinnet-i mütemârıze (akıl hastası gibi davranma). ${ }^{5}$

\subsection{Cinnet-i Menkûre (İnkâr Etme) ve Cinnet-i Mektûme (Gizleme) (Folie Dissimulee)}

Soru cevap (isticvâb) k1sminda bireylerden bazıları kendilerini hasta kabul etmedikleri için hekimlerle iletişim kurmak istemediklerinden veya hasta olduklarını kabul etmediklerinden hastalıklarını gizleyebilirlerdi. Bu sebeple her hekim soru cevap kısmına başlamadan önce gözlem ve tanı için gönderilen kişinin aile ve akrabalarından -ki bazen hasta yakınları da hastalığı inkâr veya gizleme yoluna gidebilmektedir- bu ihtimali göz önünde bulundurarak bilgi edinirdi.

Hekim birey ve bireyin yakınlarıyla iletişim kanalını kendi bulmak durumundaydı. Zira bu tür bireylerle iletişim süreçlerin nasıl işletileceği ile ilgili resmi uygulama bulunmuyordu. Hekimler, bu tür problemleri çözmede kendi başlarına bırakılmaktaydı. $\mathrm{Bu}$ sebeple iletişime geçmede bazı hekimler ciddi davranmayı tercih ederken bazıları mülayim davranmayı tercih ederdi. Hangi yol seçilirse seçilsin bireyin kendini hekimin yanında emniyette hissetmesine ve güvenmesine azami özen 
gösterilirdi. ${ }^{5} \mathrm{Bu}$ sebeple görüşme sürecince asla sert davranılmaz ve bireyin sözü kesilmezdi. $\mathrm{Bu}$ şekilde hekimler bireyin konuşmaları sırasında kendinden, yakınlarından ve yaşadıklarından bahsederken birey ve hastalı̆̆ önemli bilgilerle ipuçları elde edebilirdi.

Soru cevap kısmında bireylere inançlarına yönelik sorular da sorulurdu, bu şekilde kişinin hezeyanları hakkında bilgi edinilmeye çalışılırdı. Duygularını ve düşüncelerini yazdığ 1 metinler varsa bunlar da incelenirdi. Hafizalarının kuvvetlerini ölçmek için hangi gündeyiz, saat kaç ve dün ne yaptınız gibi gündelik hayattan ve küçük rakamlarla toplama ve çıkarma gibi hesap ile ilgili sorular sorulurdu. ${ }^{5}$

$\mathrm{Bu}$ aşamada kişinin fiziksel ve biyolojik yönden normal olmayan özellikleri de kayıt altına alınırdı. Şayet ilk gözlem ve tanılama sürecinde bazı belirsizlikler ve tereddütler oluşursa belirli bir süre geçtikten sonra işlem tekrarlanırd1. ${ }^{5,40.13}$

\subsection{Cinnet-i Mukarra (Gerçeği Söyleme)}

Osmanlı yargısında yaralama veya cinayet davası sırasında eylemi gerçekleştiren kişi ya da savunma vekili nadiren de olsa cürüm sırasında aklın bir süreliğine kaybedildiğini ileri sürerek olayın gerçekleştiğini yetkililere bildirmekteydi. Bu durumda şüpheli kontrol için ilgili kurumlara yönlendirilirdi. Burada hekimler vakaları değerlendirirken temaruz (rol yapma) şüphesi yanında şüphelinin ya da savunma vekilinin doğru söylediği ihtimalini de göz önünde bulundurarak şüphelide cismen veya aklen hastalık olma ihtimali araştırırlard1. $5,40.14$

\subsection{Cinnet-i Mütemârıze/Temaruz}

Temaruz, bir menfaat temini amaciyla birtakım subjektif veya objektif patolojik halleri şuurlu olarak abartmak yahut hiç yoktan icat etmektir. Başka bir ifadeyle hasta olmadığı halde kendini hasta gibi gösterme eylemidir. $\mathrm{Bu}$ tür davranışlar askerden kaçma, anlaşmayı feshetme, cezadan veya hapisten kurtulma gibi sebeplerde ortaya konulmaktadır. İnsan yaralama ve/veya öldürme eyleminin ağır yaptırımları olması sebebiyle cezadan kurtulmak için şüphelilerin bu yolu kullanmaları her zaman ihtimal dâhilindedir.

Hekimler, bimarhanelerde maznunların akıl sağlığını kontrol ederken Ak1 Hastalarının Sorgulama ve Kontrol Yöntemler gereğince sabıka kayd1 (vukuat/ahvâl-1 sâbıka ve vukuat), gözlem ve tıbbi muayene (muayene-i bi'l-vasita ve muayene-i fenniye/ fenn-i mülâhaza ve netice) basamaklarından oluşan yöntemlere başvururdu. Ancak şüphelide rol yapma şüphesi olduğuna kanaat hâsıl olursa o zaman ilave işlemler de uygulamaya konulurdu. Zira gerçek hasta ile hastalığı taklit edenin birbirinden ayrılması adli vakalarda adaletin tecellisi noktasında önemli bir işlevi yerine getirmekteydi.

Bir cürüm abes, uygunsuz ve çocukça bir şekilde işlenmiş ise bu eylemin cinnet halinde gerçekleşme olasılığını gündeme getirir ve bu eylemi gerçekleştiren kişinin akıl sağlığının kontrol edilmesinin gerekliliği ortaya çıkardı. Mesela bir cinayet eyleminde kişi kaçıp kendini kurtarmak yerine icra etmiş olduğu fiilden dolayı iyi bir iş yapmış gibi övünüyorsa ve mutlu oluyorsa ve de bu cinayet ile bir menfaat elde ettiyse o zaman temaruzdan şüphe edilirdi. Bir de buna kendisinin ya da dava vekilinin cürmün cinnet ile gerçekleştiğini söylenmesi durumu eklenirse rol yapma şüphesi artard..$^{5,40.15}$

Osmanlı hekimleri rol yapan kişilerin (mütemâriz) akıl hastası gibi davranmalarının hiç kolay olmadığını iyi bilmekteydiler. Bir hastalığ 1 taklit edebilmek için olağanüstü yeteneğe ve taklit ettiği hastalıkla ilgili epeyce bilgiye sahip olmaları gerektiğinin farkındaydılar. Hastalığ hastalıkla ilgili hareketleri gerçekleştirirken dahi sahte bir yüzle ve abartılı yüz ifadesiyle gülünç bir hale düşebiliyorlardı. Bu kişiler hangi hastalığı taklit ederlerse etsinler her birinde aşırılığa varan bir tavır ortaya koymaktaydılar. Bunun yanında kendilerine sorulan sorulara gerçek şekliyle değil de aptalca ve tuhaf bir şekilde cevap vermeleri, istenilenin tersini yapmaları rol yaptıklarını güçlendiriyordu. ${ }^{5}$ 
Osmanlı hekimleri, bir kişinin/şüphelinin rol yapıp yapmadığını morfin, eter gibi kimyasal maddeler kullanarak daha kolay tespit etme imkânları olduğu halde insan sağlığı açısından zararlı olması sebebiyle bu yöntemleri kullanmadıkları görülmektedir. Bunun yerine daha insanî yöntemler tercih etmekteydiler. Örneğin müşahede altında bulunan hastanın duyabileceği biçimde $b u$ adamda cinnet var amma geceleri gürültü etmediği ve önüne konulan taamı [yemeği] dă̆ıtmadĭ̆ bakmadığ $i$ için şüphe ederim şeklinde ifadeler söyler ve kişiyi takip ederlerdi. Şayet söylenenleri yaptığı tespit edilirse rol yaptığ kesinleşirdi.

Bunların yanında şüphelilerin rol yaptıklarının tespitinde akıl hastalıklarında görülen fiziksel ve biyolojik hastalık belirtilerini de gözlemlerlerdi. Zira bu hastalarda uykusuzluk, acı çekmeme (fikdân1 elem), iştahsızlık (dalâlet-i iştihâ), kabızlık (inkıbazlık), denge bozukluğu (ihlilalat-1 deverâne) ve nefes bozukluğu (teneffüsiye) gibi belirtilerden biri veya birkaçı izlenirdi. Rol yapan kişiler/maznunlar bu belirtileri taklit edemez ve kendilerini ele verirlerdi. ${ }^{5}$ Örneğin Rumeli muhacirlerinden olan İbrahim'in Adapazarı Çarşısı'nda iki kişiyi balta ile katletmesi hadisesinde cinayetleri cinnet halinde işlediğini iddia etmiş, ancak hekimlerce yapılan kontrol ve tanı sürecinde cinnet halinde işlemediği hekim raporlarınca tespit edilmiştir. ${ }^{40.16}$ Bir başka gözlem süreci de Geredeli Hatice'nin babasını öldürme hadisesinde görülmektedir. Geredeli Hatice'nin cinnet iddiasıly babasını öldürdüğü iddia edilmiştir. Hekimler tarafından gözlem ve kontrol sürecinde gerçekler tespit edilmiş, Hatice'nin cinnet geçirmediği, pederinin dayısı tarafından öldürüldüğü gün yüzüne çıkarılmıștır. Son örnek kadın cinayeti üzerine olup İmamoğlu Recep karısını ve kızını cinnet geçirerek öldürdüğünü ifade etmiş, ancak gözlem ve kontrol süreçlerinde akıl sağlığının yerinde olduğu ve cinayetleri salim kafayla işlediği raporlanmıştır. $\mathrm{Bu}$ rapordan sonra adli yargılama süreci devam ettirilmiştir. ${ }^{40.17}$

\section{Cinnet Kaynaklı Saldırı Eğilimi Bulunan Hastalıklar}

Osmanlı hukukunda ve tıp alanında cinnet saldırılarını gerçekleştiren kişilerde görülen hastalıkların hukuki boyutunu Hukuk Fakültesi Müderrisi olan Cevdet Ferid, Yeni Ceza Hukuku bağlamında irdelerken tıbbi yönünü akıl hastalıkları uzman doktorları Avni Mahmud ile Mazhar Osman ele almaktadır.

Osmanlı Yeni Ceza Kanunu'na göre, insanların cinnet saldırılarını gerçekleştirmesinde etkili dört hastalıktan bahsedilmektedir. Bunlar Manie, Melankoli, Hezeyan ve Ateh'tir.

1) Sabit Fikirli/ Manie, k1smen cinnet geçirip aklında sabit bir fikre sahip olan kişilerde görülür. Gülünç ve garip şekilde bağlanma eğiliminde olan bu kişiler genel itibariyle iki şekilde belirti gösterirler. Bunlardan biri düşkün /besitda diğeri ise saldırgan/delie mainiaque biçimdedir. İkinci kısımdaki kişilerde cinnet saldırıları her zaman görülmektedir.

2) Melankoli/ Lypematuie, $\mathrm{Bu}$ rahatsızlıkta kişi genellikle düşkündür. Bunun yanında hayal görme/ hallueinaion, kara sevda/ hypocondrie gibi çeşitli şekillerde de kendini gösterir.

3) Hezeyan/ Siytematisation Delirante, diş dünyadan etkilenmek suretiyle doğru düşünme yetisini kaybetmiş olmadır.

4) Ateh/demeuce, akıl sağlığının yitirilmesi durumudur. Kısmî olabildiği gibi sürekli de olabilir. Ateh durumundaki kişi bazen aklını da kısa ya da uzun süreli yitirebilir. $\mathrm{Bu}$ durumda kendisinin çıldırtıcı fikirleri biraz daha baskın olup makul fikirleri karışık hale gelir. Hafızası daha zayıflar. Hatırındaki bilgiler dağınık şekilde kendini gösterir. Bu durum bazen de tam akıl sağlığı yerinde olan kişilerde görülebilir ki bunların ilk önce hafizası zayıflar ve daha sonra tamamen kaybolur. Böyle bir durumda akıl sağlığı yerinde olarak iş yapma imkânı ortadan kalkar.

Matuhların davranışlarında farklılık gözlenebilir. Bazısı yürür bazısı ise bir yerde 
saatlerce kalır. Atehler birkaç kısma ayrılır: 1) Ateh Şebâbî, yorgunluk ve heyecan neticesinde gençlerde görülür. 2) D. Vesenarique mecnunlarda görülür. Ateh Şeyhi, yaş ilerledikçe ortaya çıkan bir rahatsızlıktır. Yaşlanmaya bağlı beyin fonksiyonların yitirilmesi ve manevi sebeplerden dolayı aklın yitirilmesidir. ${ }^{40.18} 3$ ) D. Toxipue vardır ki alkol, tütün, afyon ve benzeri bağımlılık yapan maddelerin fazla tüketilmesi ile gerçekleşir. Bu ateh genellikle kalıtımsaldır. ${ }^{18}$

Avni Mahmud ise Muhtasar Emrâz-1 Akliye isimli eserinde cinnet cinayetleri işleyebilecek kişilerin hastalıkları hakkında şu bilgileri vermektedir. ${ }^{5}$

Cinin-i Gayr-i Müteammime, cinnet içinde öldürme hususiyetinin çoğunlukta olduğu rahatsızlı türüdür. Hezeyan-1 Mezhebiyye hastalığında hasta, güya bir kimsenin isyanından dolayı öldürülmesine dair Cenab-1 Hakk'tan emir aldığını ve onun öldürülmesi için görevlendirildiğine inanır. $\mathrm{Bu}$ zanla hareket ederek o kişiyi öldürür. $\mathrm{Bu}$ kişiler kendilerini aziz ve şerif kabul ettiklerinden yakalandıkları zaman gerek hezeyanları gerekse öldürme hadisesi hastalığına işaret etse de bu kişilerin tutum ve davranışları bunların hastalıklarını şüpheli hale getirir. $\mathrm{Bu}$ nedenle de bu tür hastalık neticesinde gerçekleşen eylemleri cinnet eylemi olarak başkalarına kabul ettirmek de doktorları zor durumda birakmaktadır. Bu kişiler, gözetim altına alındığında zulme uğratıldıklarına inandıklarından intikam duygusuyla bir veya birden fazla kişiyi planlayarak öldürme ihtimali bulunur. $\mathrm{Bu}$ durum hastanede bile gerçekleşebilir. ${ }^{5}$

Sar'a, nevroz grubunda yer alan sar'a hastalığının sebebi tam olarak

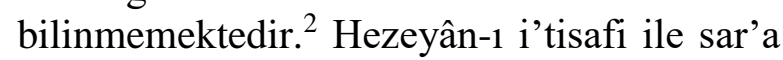
en fazla cinayet işleyen hastalar olmaktadırlar. Sar'a sebebiyle gerçekleşen öldürme eylemi veya yangın çıkarma hareketi aniden, süratli ve şiddetli biçimde gerçekleşebilir. Hastalık süresince irade kaybedildiği için cezai sorumluluğu yoktur. Bu sebeple en çok taklit edilen hastalıktır.
Ma'lûliyet-i Dimâğ (Aklın Gitmesi), doğuştan veya sonradan bu hastalığ olan bir kişi, işlediği suçu genellikle gülünç, abes, münasebetsiz ve temyizden kudreti bulunmadan gerçekleştirir. Bu tür rahatsızlığı olanlarda katletme eylemi oldukça nadir yaşanır. Ma'lûliyet-i dimâğıye hastaları bilhassa namusa saldırı, tecavüz (hetek-1 1rz), hırsızlık suçlarını işlerler. $\mathrm{Bu}$ rahatsızlık temelinde şiddetli bir cinsel dürtü bulunmaktadır. Bu hastalar cinsel uzuvlarını her an gösterebilirler.

Ahvâl-i Manyaviye, manya-yı hadde hastalığ 1 herkes tarafından korkulan bir hastalık olmasına rağmen bunda yaralama ve öldürme eylemi nadir olarak gerçekleşir. Bu kişiler rahatsızlıkları sırasında etraftaki eşyalara daha çok öfke yöneltirler ve zarar verirler. Hastalık ileri safhaya ulaştığı zaman gerçekle hayal birbirine karışır. Bu sebeple korku, şiddet ve hezeyanla bir veya birden fazla kişiyi planlayarak öldürebilirler. $\mathrm{Bu}$ rahatsızlığ 1 olanlar genellikle yalan söylerler ve iftira atarak insanların namus ile onurunu zedeleyici davranışlarda bulunurlar.

Ahvâl-i Malhülyaviye, bu hastalıkta hastalar nadiren suça karışmakla birlikte genellikle intihara meyillidirler. Ancak üzüntüyle oluşan cinnette (cinnet-i mağmume-i haddede) öldürme fiili de ortaya çıkabilir ki bunda öldürme sebebi düşmanlık ve olumsuz ilişkiden değil, aksine aşırı sevgiden gerçekleşir. Burada kişi hezeyan kaynaklı bir his ile sevdiği bir kimseyi, çektiği işkence, eziyet ve çileden kurtarmak için öldürdüğünü ifade eder.

Cinnet-i Sabâvet, çocukluk ya da gençlik çağında ortaya çıkan bu hastalıkta kişinin aklının ortadan kalkmasıyla aniden, düşünmeden ve iradesiz olarak sebepsiz yere hırsızlık, yangın ve öldürme, eylemlerini gerçekleştirirler.

Cinnet-i Nefâsiye, bu cinnet türünde hastalar genellikle hırsılık veya bir veya birden fazla kişiyi planlayarak öldürme suçunu iradeleri dışında içten gelen dürtüyle işlerler. 
Cinn-i Semiye, Cünûn-1 Semiyede ve özellikle cinnet-i küûlliyyenin (alkol cinneti) etkisi altında olan hastalar genellikle intihara eğilim gösterir. $\mathrm{Bu}$ rahatsızlığı olanlar arasında yangın çıkarma, hırsızlık, namusa ve ırza saldırı gibi olaylar görülebilir. Hastalığın ileri olduğu durumlarda heyecan ile bir veya birden fazla kişiyi planlayarak öldürebilirler. ${ }^{5}$

Felc-i Umûmî, bu rahatsızlıklarda çoğunlukla yaralama ve kabahat eylemleri gerçekleşir. En çok hırsızlık, namusa taarruz, evrakta sahtecilik, emniyeti bozma eylemleri görülür. Nadiren olsa da bir veya birden fazla kişiyi planlayarak öldürebilirler. Bunlar değersiz ve ehemmiyetsiz şeyleri çalarlar. Muayene sirasında bunların bunaklıkları gözlemlenir.

Mazhar Osman, Tebâbet-i Ruhiye isimli eserinde cinnet ile ilgili hususta özellikle daha ürkütücü bilgiler vermekte ve Katl-i Cinnet üzerinde durmaktadır. $\mathrm{Bu}$ cinnet türünde öldürme arzusu yüksek olan ve kan kokusu ile rahatlayan hastaları tanımlamaktadır.

Cinnet-i Katl, Cinnet-i Katl ile Asl-i Katl birbirinden ayrı özelliklere sahiptir. Cinnet-i katl hastalığında öldürme eylemi sebepsiz veya küçük bir sebepten gerçekleştirilebilir. Hasta öldürmekten haz alır. Bu sebeple kontrol altına alınmadığı müddetçe öldürme eylemini sürdürür. $\mathrm{Bu}$ hastalar, hezeyanı olmayan, muhakemesi düzgün, aklı başında olan kişiler olarak toplum içinde bulunurlar, ancak varlıkları büyük bir tehdittir. ${ }^{34}$

Cinnet-i Mağmume, intihar etme hastalığıdır. Akıl hastalıklarının birçoğunda görülür. İntiharın cinnet sayılabilmesi için aile geçmişinde intihar vakasının yaşanmış olması ve intihar eğiliminde olunması gereklidir. İntihar vakalarının çoğunda psikopat denilen mecnunlar ve sinirli olan kişiler vardır. Hayatında üzüntü, sefalet, mahrumiyet, 1stırap ve kedere dayanamayıp intihar edenler de bulunmaktadır. Bu sebeple her intihar eden mecnun mudur diye araştırılması ve bunun sonucunda karar verilmesi gereklidir. ${ }^{34,36}$

\section{Cinnet Kaynaklı Saldırılar}

Osmanlı toplumunda 1831-1917 y1lları arasında yaşanan ve arşiv kayıtlarına yansıyan cinnet kaynaklı saldırıların toplam vaka sayısı 49'dur. $\mathrm{Bu}$ vakalarda cinnet geçirip etrafındaki insanları yaralayan ve öldürenlerin tamamı erkektir. Cinnet saldırılarının 33'ü $\quad(\% 67) \quad$ tanıdık olmayanlara/yabancilara ve 14'ü (29) aile içine yönelik gerçekleşmiştir. Ayrıca 2 (\%4) intihar vakası yaşanmıştır.

Cinnet saldırısı sırasında zarar görenlerin sayısı 80 kişi olup bunların 56'sını erkekler (\%70), 20'sini kadinlar (\% 25) oluşturmaktadır. 4 kişinin (\%5) cinsiyeti kayıtlarda belirtilmemiştir. Yerleşim yerlerine göre dağılımda 37 vakanın (\%76) şehir merkezlerinde 12'sinin de (\%24) kırsal kesimde yaşandığı görülmektedir.

Cinnet saldırılarında saldırı aracı olarak bıçak başta olmak üzere kılıç, kasatura, odun, balta, tabanca ve tüfek kullanıldığ görülmektedir. Cinnet geçirenlerin meslek grupları veri setlerinde açıkça gösterilmemekle birlikte Kâmus-1 Tibbi'de askerler, gemiciler, muallim, avukat, yazar, tabip ve diğer meslek gruplarında görüldüğü aktarılmaktadır. Buna ilaveten erkeklerde cinnetin 14-45 yaş aralığında, kadınlarda ise 25-30 yaş aralığında daha fazla görüldüğüne de vurgu yapilmaktadır. ${ }^{2}$

\subsection{Aile İçine Yönelen Cinnet Kaynaklı Saldırılar}

Aile içi şiddet birçok imkâna rağmen çağımızda dahi tam anlamıyla önlenebilmiş değildir. ${ }^{37}$ Osmanlı toplumunda da aile içi şiddetin üzücü bir şekilde yaşandığ görülmektedir. Cinnet anında birey, bu cinnetini çevresinde savunmasız olarak bulunan karısına, çocuklarına, kardeşlerine ve aile büyüklerine yöneltmektedir. Araştırma döneminde tespit edilen cinnet saldırılarının 14'ü aileye yönelik gerçekleşmiştir. $\mathrm{Bu}$ sayı genel cinnet saldırılarının \%29'unu oluşturmaktadır. Cinnet geçiren kişi, saldırı sırasında ilk önce karısına zarar vermektedir. Zira 14 saldırının 7'sinde failin karısını öldürdüğü görülmektedir. Yani aile içi şiddet 
saldırılarının \%50'si evin hanımına yönelmektedir.

Aile içi cinnet saldırılarında aile bireyleri savunmasız yakalandıkları için olayların \%80'i ölümle sonuçlanırken mağdurların \% 20 'si de ancak yaralı olarak kurtulabilmiştir Aile içi cinnet saldırıları sonucunda 4 yaralanma ve 16 ölüm gerçekleşmiştir. Aile içi cinnet saldırıları ile vaka örnekleri şöyledir:

Bolu Sancağında Gerede kazasında Salur köyünde yaşayan Hüseyin, karısı Emin kızı Fatma'y1 evinde uyurken 23 Mart 1859 tarihinde saat beşte tüfek ile vurur. Hüseyin kolluk kuvvetleri tarafından yakalanır ve hakkında tahkikat başlatılır. Hüseyin olayı cinnet anında gerçekleştirdiğini söyler. $\mathrm{Bu}$ durumu Hüseyin'in annesi ve çocukları da doğrularlar. Hüseyin'in daha önceden de cinnet geçirmiş olduğundan hareketle karısını öldürme eylemini cinnet halinde işlediği şeklinde rapor düzenlenir. $\mathrm{Bu}$ rapor üzerine hâkim, Hüseyin'i Ceza Kanununun 41. maddesi gereğince serbest bırakır. ${ }^{40.19} \mathrm{Bu}$ hadise Avni Mahmud'un belirttiği Toptaşı Bimarhanesi'nde daha önce Tabib-i evvel olarak görev yapmış olan Avrathisarlı Mehmed Emin oğlu Hüseyin'in vakasına da benzer. Hüseyin, karısı Hatice'yi öldürmesi sebebiyle Nezaret, Hüseyin'i Bimarhane'ye gönderir. Burada Hüseyin'in tahkikatı tamamlanır ve raporu düzenlenir. Bu rapora göre Hüseyin'in akıl sağlığının yerinde olmadığı malihülya hastası olduğu ve cinayeti hezeyan sebebiyle kendisini öldürmek isteyen Arnavutlar'dan kurtulmak için işlediği sonucuna varılır. Bu sebeple de Hüseyin'in işlediği cinayetten sorumlu tutulamayacağı Nezaret'e bildirilir. ${ }^{5}$

Bir başka cinnet hadisesi ise Midilli'de yaşayan Yunanlı Nikola tarafından gerçekleştirilir. Nikola, beş altı aylık hamile karısın1, kayınvalidesini ve kızını öldürür. Nikola'nın bu cürmü işlediği sırada akıl sağlığının yerinde olup olmadığının kontrol edilmesi gerektiğine dair mahkeme kararı Tibbiye Mektebi'ne gönderilir. Yapılan incelemelerde eylemi gerçekleştirdiği sırada şuurunun yerinde olmadığı tanısı konulur ve
Nikola, sağaltım için bimarhaneye kontrollü olarak gönderilir. ${ }^{40.20}$

Kudüslü Abdüllatif' in cinnet saldırısı sonucunda karısı, kayınvalidesi ve kız kardeşi hayatta kalmayı başarabilmiştir. $\mathrm{Bu}$ şekilde gerçekleşen saldırılarda bu aile nadir olarak hayatta kalanlara örnektir. Cinnet geçirdiği yapılan incelemeler sonucunda tespit edilen Abdüllatif, Fransız Hastanesi'ne sağaltım için yatırıldı. Hastalığının iyileşmesi üzerine oğlu Mehmed Ali'nin sorumluluğunda kefaletle memleketine gönderilmesine karar verildi. Rahatsızlığının nüksetmesi durumunda derhal resmi makamların bilgilendirilmesi gerektiğine dair protokol imzalatıldı. ${ }^{40.21}$ Benzer şekilde cinnet kaynaklı saldırılar arasında Bosna Eyaleti Güzelcehisar kazasında yaşayan Salih'in babasi Recep'i, üvey annesi Hafsa'y1; Antalyalı Hafız Mehmed'in, babası Abdi'yi; Bolulu Yusuf'un, kız kardeşi Fatma'yı; İslam'ın, kardeşi Celaleddin'i; Giritli Rifat'ın, annesini öldürmesi say1labilir. ${ }^{40.22}$

Cinnet anında insanın insanlıktan çıktığı, en savunması çocuklara bile yaşam hakkı tanımadığı ortaya çıkmaktadır. Bu tür kan donduran hadiselerden biri Zelhova'ya bağl1 Resilova köyünde yaşanır. Bu olayda Halil oğlu Mustafa dokuz aylık çocuğu Halil'i öldürür. $\mathrm{Bu}$ olayın kolluk kuvvetleri tarafindan öğrenilmesi üzerine Mustafa derhal tutuklanır. Henüz bir bebek olan Halil'in babası tarafindan katledilmesi ak1 dışı olarak düşünüldüğünden Mustafa, yetkili makamlarca akıl sağlığının kontrolü için bimarhaneye sevk edilir. ${ }^{40.23}$ Mustafa'nın akıl sağlığıyla ilgili rapora ulaşılamasa da onun bu eylemi şuurlu olarak yapma ihtimali bile ürperticidir.

\subsection{Yabancıya/ Tanımadıklara Yönelen Cinnet}

Osmanlı toplumunda aileye yönelen cinnetin dışında yabancıya yönelen cinnet saldırıları da görülmektedir. Özellikle bu tür saldırılar, aralarında herhangi bir bağ bulunmayan ve çıkar çatışması olmayan kişi ya da kişilere yöneldiği için cinnet saldırısı olma ihtimalini daha çok arttırmaktaydı. Bu 
sebeple de adli merciler veya kolluk kuvvetleri faillerin eylem sirasında akıl sağlıklarının yerinde olup olmadığının kontrolü için şüphelileri, bimarhane, darüşşifa, hastane veya Tibbiye Mektebine gözlem ve tanı için göndermekteydiler. İncelenen vakalar içinde 33 vakada yabancıya yönelik cinnet saldırısı gerçekleşmiştir. Bu oran, genel saldırıların \% 67'sini oluşturmaktadır. Cinnet saldırılarından 58 kişiden yalnızca 3'ü zarar görmeden kurtulmuş, 18'i yaralanmış, 37'si ise hayatlarını kaybetmişlerdir. $\mathrm{Bu}$ saldırılardan 47 erkek cinnet geçiren kişiden zarar görmüşlerdir.

Cinnet yönünün bireysel ve toplumsal olarak görüldüğü örnek vakalar şöyledir: Çankırı'nın Ovacık köyünden Çorum'un Seyyid Murad köyüne misafir olarak gelen Kapısızoğlu Ali, bu evin sahibinin oğlu olan Said'i gece vakti bahçede öldürür. Bunun üzerine maktulün ailesi, Meclis-i Vala'ya şikâyette bulunur. Yapılan tahkikatta Ali, Said'i keçi oğlağı zannederek kestiğini, yetmiş yaşını geçtiğini ve cinnet durumunda bu eylemi gerçekleştirmiş olduğunu söyler. Meclis-i Vala da Ali'nin akıl sağlığının incelenmesi ve sağaltım edilmesi için Darüşşifa'ya gönderilmesine karar verir. ${ }^{40.24}$

Ürgüb'ün Kurşunlu nahiyesinde Mehmed oğlu Hüseyin ile karısı Akça Hatun birlikte arabalarını tamir ederler. Tam bu sırada Saadeddin eline geçirdiği tüfek ile Hüseyin'i hedef alır ve ateş eder, ancak kurşun Hüseyin'in yerine Akça Hatun'a isabet eder. Akça Hatun, aldığı kurşun yarasıyla iki ay yaşayabilir. $\mathrm{Bu}$ cürüm sebebiyle başlatılan işlemlerde Saadettin'in yirmi otuz günde bir cinnet nöbeti geçirdiği, bu sebeple de 41 . madde gereğince cezadan muaf olması dava vekili tarafindan talep edilir. Ancak serbest bırakılmasının tehlikeli olacağı sebebiyle Saadettin, sağaltım edilmek üzere gerekli tedbirler alınarak İstanbul'a hastaneye gönderilir. ${ }^{40.25}$

Aydın Güzelhisar'da yaşayan Menzilcioğlu Terzi Ahmet, meslektaşı Terzi İstovri ile Mehmed'i yaralar ve terzi Halil'i öldürür. Bunun üzerine Terzi Halil'in karısı
Hatice ve çocukları Ahmed'den davacı olurlar. Ahmed, olay anında cinnet geçirdiğini belirtir, babası ve olay anını görenler de Ahmed'in cinnet halinde saldırıyı gerçekleştirdiğine şahitlik ederler. Ahmed'in babası, oğlu için müftüden cinnet halinde gerçekleşen eylemden kişinin sorumlu tutulamayacağına dair bir de fetva alır. Meclis-i Vala, tıbbi yönden değerlendirmek, gözlem, tanı ve sağaltım için durumu Manisa Darüşşifası'na havale eder. ${ }^{40.26}$

Cinnet saldırıları içinde amok tarzı saldırı örneklerine de rastlamak mümkündür. Örneğin Üsküp sancağı Pirlepe kazası merkezindeki Hükümet Konağ 1 Zabit Koğuşu'nda bulunan Abdurrahim'in bir piyade onbaşı tüfek ve revolverlerini alarak sabah saat 6.00 'da çarşıya gider ve etrafa rastgele ateş etmeye başlar. Bu sırada çarşıda bulunan ikisi erkek, biri kadın üç Hıristiyan ile Müslümanlardan ikisi çocuk ve ikisi asker olmak üzere toplam yedi kişiye kurşun isabet eder. Bunlardan içinden üç Hristiyan ölür diğerleri de yaralanır. Abdürrahim sağ olarak yakalanır, ancak Pirlepe'de yaşayan Hıristiyanlar bu saldırıdan çok tedirgin olurlar. Tahkikatın derinleştirilmesi ve saldırının cinnet saldırısı olup olmadığının incelenmesi için Manastır Valiliği, merkezi hükümetçe görevlendirilir. ${ }^{40.27} \mathrm{Bu}$ tip saldırılar toplumda infiale sebep olabilecek tarzdaki saldırılardır. Zira saldırıyı düzenleyen kişinin zabit olması, Hıristiyan kişilerin burada ölmesi Osmanlı Devleti'ne birçok yönden zorlu bir süreç yaşatabilecek boyuttadır.

Manastır'da Serfiçe Hapishanesi muhafazasında görevli Zabtiye Bölüğü askerlerinden Behlül'ün cinnet geçirerek arkadaşlarından birini katlettiği ve kapanmış olduğu koğuştan Zabtiye görevlilerine ateş etmeye devam ettiği, buna karşın failin ancak etkisiz hale getirilerek durdurulabildiği görülmektedir. ${ }^{40.28}$

Efe Mustafa'nın beş kişiyi öldürmesi hadisesi ile Tepeköy'den Ahmed'in eline geçirdiği baltayla etrafa saldırması ve bu sırada bir kaç kişiyi yaralayıp üç kişiyi de öldürmesi hadisesi, Gülhane Hastanesi 
görevlilerinden Bekir'in kasatura ile Topkapı Sarayı'nda nöbet tutan üç askerin üzerine saldırma hadisesi de amok tarzı saldırı tipini oluşturan diğer örneklerdir. ${ }^{40.29}$

\section{Yargılama, Gözlem ve Tanı Sonrası Süreç}

Osmanlı hukukunda daha önce de belirtildiği gibi şüpheliye bir suçtan dolayı ceza verilebilmesi için şüphelinin suçu işlediği sırada maddi ve manevi unsurlarıyla birlikte gerçekleştirmesi gerekmekteydi. Cinnet gibi bir rahatsızlık durumunda gerek klasik dönem Osmanlı hukukunda gerekse Ceza Kanunnâme-i Hümayunu'nun 41. maddesinde belirtildiği üzere hapis ya da k1sas cezası uygulanmamaktaydı. ${ }^{25,38,39}$ Nitekim şüphelinin yetkili makamlarca gözlem ve tanı süreçlerinin tamamlanması ve yaralama ve öldürme eylemlerini cinnet halinde gerçekleştirdiğinin raporlanması durumunda ilgili mevzuat hükümlerine göre yargilama sonlandırılırdı. ${ }^{40.30}$ Bundan sonra yapılacak işlemler Bimarhaneler Nizâmnâmesi ile Yeni Kânun-1 Cezâ'ya göre yürütülürdü. Buna göre mecnun olduğu raporlanan kişinin kendisi ve topluma karşı tehlike boyutuna göre yapılması gerekenlerin hüküm altına alınması gerekirdi.

Mevzuat hükümlerine göre gerekli tedbirler alınarak mecnunun ailesine/vasisine teslimine yahut sağaltım için Bimarhaneye gönderilmesine hekim raporlarına göre hâkimler karar verirdi. Şayet maznunun serbest bırakılmasının tehlike oluşturacağ 1 mahkemece takdir edilirse şüpheli hakkında yürütülecek resmi işlemler tamamlanıncaya kadar kendisini muhafaza etmeleri için kolluk kuvvetlerine teslim edilirdi. Bunun yanında mecnuna bir vasi tayin edilmesi gerekirse o zaman da kanunun 355. maddesi devreye girer ve mahkemece vasi tayin edilirdi. Hastaların sağaltım kararı sağlık kurumlarınca verildiği takdirde burada süreç başlatılır ve hastalığın tedavisi tamamlana kadar sürerdi. Tedavi tamamlandıktan sonra ailenin başvurusu, yetkili makamların uygun görmesi durumunda kolluk kuvvetleri ve ailesinden vasi olan kişinin nezaretinde memleketlerine gönderilirlerdi. 5,18,25, 40.21,40.31

$\mathrm{Bu}$ sürece örnek olarak İstanbul'da Bebekli Ali'nin yaşadıkları gösterilebilir. Cinnet geçirerek bir şahsı öldüren Bebekli Ali'nin iyileşmesi ve taburcu vaktinin gelmesi üzerine Ali'nin kardeşi İbrahim Meclis-i Vala'ya dilekçe yazar. Bu dilekçede kardeşinin birkaç seneden beri Bimarhane'de sağaltım gördüğünü ve iyileştiğini, hastaneden çıkarılması durumunda kendi sorumluluğunda olacağını ve rahatsızlanması durumunda tekrar hastaneye getireceğini taahhüt eder. Bunun yanında maktulün veresesiyle mahkemelik olma durumunda Bebek köyünde yaşayanlarla birlikte diyetin kefaletle ödeneceğini ve adli süreçte sorumluluğu üstlendiğini bildirir. ${ }^{40.31}$ Burada görüldüğü gibi hastaneye giriş ve çıkışlar mevzuat hükümlerine göre yürütülmekte olup kefalete ve yetkili makamların onayına tabiidir. Kuruma giriş ve çıkış süreci içinde birey/hasta tek başına gönderilmeyip vasisi ve iki kolluk kuvvetiyle birlikte yerleşim yerlerinden alınırlar ve ulaştırılırlardı.

\section{SONUÇ VE ÖNERILLER}

Günümüz basın yayın organlarının kullandığı cinnet kavramı, Osmanlı Devleti'nde akıl hastalıklarının genel adıdır. Bununla birlikte bazı akıl hastalıklarına bağlı olarak ortaya çıkan bir anlık öfke, şuur kaybı ve duygu durumunda yaşanan bozukluk ve buna bağlı olarak bireylerin gerçekleştirdiği saldırilardırlar da cinnet olarak adlandırılmaktadır. Cinnet sebepli hastalıklar üzerinde dönemin uzmanları isimlendirme çalışmaları yapmışlarsa da birlik sağlanamamıştır. Cinnete sebep olan hastalıklar arasında Cinin-i Gayr-i Müteammime, Sar'a, Ma'lûliyet-i Dimâğ, Ahvâl-i Manyaviye, Ahvâl-i Malhülyaviye, Cinnet-i Sabâvet, Cinnet-i Nefâsiye, Felc-i Umûmî ve Cinnet-i Katl yer almaktadır.

Osmanlı tıbb1 ve hukuku, akıl hastalıklarının varlığını kabul etmektedir. Ancak kendi görev alanları yönüyle cinnet rahatsızlığını ve hadiselerini farklı değerlendirmektedir. Hukuk, cinnet 
durumunda bireyin cezaî ehliyeti üzerinde dururken tıp bireyin hastalığının kontrol, tanı ve tedavisi ile ilgilenmekteydi. Bu sebeple de hukuk terminolojisinde hastalıkların adları ceza kanunlarında sınırlı olarak yer alırken tıp alanında daha detaylı olarak bulunmaktadır.

Herhangi bir cinnet hadisesinde eylemi gerçekleştiren kişinin, kendisi, ailesi ve dava vekili tarafından akli melekelerinin yerinde olmadığı iddia edildiğinde veya kolluk kuvvetleri yahut mahkeme tarafindan her hangi bir şüphe oluştuğunda bu konuda bilirkişilere müracaat edilirdi.

Osmanlı Klasik Dönemi'nde müftü, yetkin olarak fetva üzerinden bireyin akıl sağlığıyla ilgili hâkime bilirkişilik yaparken tıbbın gelişmesiyle birlikte hâkimlere hekimler de bilirkişilik yapmaya başladı. Modern dönemlerde hekimlerin bilirkişi olarak görevleri artarken müftülerin bu alandaki yetkileri azaldı.

Akıl sağlığının kontrol sürecinin belirli bir düzen dâhilinde ve kurallara bağlı olarak işletilmesi, Bimarhanelere Dair Nizâmnâmenin hazırlanması ve uygulamaya konulmasıyla başlatıldı. Buna ilaveten müftü ve hekim arasında ikiliğin ortadan kaldırılması ve bu alandaki sürecin kurumsallaştırılması için Ceza Kanunâme-i Hümâyûnu'nun 41. maddesi uygulamaya konuldu ve müftülüklerin yetkisinden ayrıştırıldı. Yeni Ceza Kanunu ile bu uygulamadaki boşluklar dolduruldu.

Cinnet saldırısında bulunan şüpheliler; gözlem ve tanı için müşahede kurumlarına gönderildiklerinde Tip Kanunu, Bimârhânelere Dair Nizâmnâme, Zabtiye Nezareti tamimi ve Akıl Hastalarının Sorgulama ve Kontrol Yöntemleri doğrultusunda işlemleri yürütüldü. Özellikle ceza sorumluluğundan kurtulmak için akıl hastası rolüne karşı gerekli tedbirler alındı. Bireylerin gözlem, tanı ve kontrollerinde tecrübeye sahip oldukları, görevlerini yaparken insanî hassasiyetlere özen gösterdikleri, iş yüklerinin çok olmasına rağmen adaletin tecellisi için azami dikkat gösterdikleri anlaşılmaktadır. Müşahede süreci tamamlanıp akıl sağlığı raporları mahkemeye teslim edildiğinde cinnet halinde cürüm işlenmişse yargılama sona erdirildi. Daha sonra hekimlerin önerisine göre mahkeme, vasi tayini ve sağaltım süreçlerini başlattığ1 görülmektedir. Böylece kişi, hekim raporuna bağlı olarak ya ailesine teslim edilir ya da Bimarhaneye yatırıld.

1831-1917 yılları arasında kayıtlarda yer alan 49 cinnet saldirısinın tamaminı erkeklerin gerçekleştirdiği görülmektedir. Bu durum erkeklerin geçici süreyle akıl sağlı̆̆ını yitirme eğiliminde olma ihtimalinin yüksekliğini göstermektedir. $\mathrm{Bu}$ sebeple konuyla günümüz psikiyatrlarının konuyla ilgili araştırma sonuçları cinnet olaylarının gerçekleşmesini önlemeye katkı sağlayabilir.

Cinnetin aile içinde gerçekleşmesi durumunda ölümle sonuçlandığı ortaya çıkmaktadır. Cinnet bir hastalıktır, ancak bu tür rahatsızlıkların önceden belirtilerinin olduğu, bu durumda bireylerin ailesi tarafından hekime başvurmalarının ne denli önem taşıdığı ortaya çıkmaktadır. Aksi durumda telafisi olmayan y1kımlara sebep olduğu yaşanan örneklerden anlaşılmaktadır. Bazı meslek gruplarında belirli periyotlarla akıl ve ruh sağlığının kontrollerinin ciddi olarak yapılmasının önemi aşikârdır.

Cinnetin yalnızca amok tarzı saldırıları kapsamadığı, hukuki ve tıbbi olarak Osmanlı hukuku ve bilim insanları tarafindan farklı hastalıkların tanımlayıcısı olarak kullandıkları tespit edilebilmektedir.

Çağımızda da cinnet saldırıları görülmeye devam etmektedir. $\mathrm{Bu}$ durum insanlığın cinnet saldırılarını önlemeye yönelik eylem planlarını daha çok geliştirmeye ihtiyacının olduğunu göstermektedir. $\mathrm{Bu}$ alanlarda yapılan çalışmaların çok kıymetli olduğu muhakkaktır. $\mathrm{O}$ halde bu tür saldırıları önlemek için yapılan çalışmaların tabana yayılmasında, kamu kurum ve kuruluşlarıyla sivil toplum örgütlerine büyük sorumluluk düşmektedir. Özellikle cinnet belirtilerinin ne olduğu ve bunu aşmak için bireyin yakınlarının neler yapması gerektiği konusunda uzmanların rehberliğinde eğitim 


\section{KAYNAKLAR}

1. Muallim, N. (1318). Lûgât-i Naci. İstanbul: Asr Matbaası.

2. [Bilmen], Ş.M. (1328). Kâmûs-1 Tibbî. C. 1-2. Misır: Osmanlı Matbaası.

3. [Uludağ], O.Ş. (1925). Beş Buçuk Asırlık Tarihi Türk Tababeti. İstanbul: Matba'a-i Amire.

4. Dols, M.W. (2013). Mecnun: Ortaçağ İslam Toplumunda Deli. İstanbul: Pinhan Yayıncilık.

5. Mahmud, A. (1326). Muhtasar Emrâz-1 Akliye. İstanbul: Ahmed İhsan ve Şürekâsı Matbaacılık Osmanlı Şirketi.

6. Ergin, O. (1911). Müessesât-1 Hayriye-i Sihhiye Müdüriyeti. İstanbul: Matbaa-yı Arşak Garoyan.

7. [Gökay], F.K. 1924. Aklî Hastalıkların Teşhisi ve Tedavisi İstanbul: Kadir Matbaası.

8. Artvinli, F. (2020). “Osmanlı Devleti’nde Deliliğin Tibbileştirilmesi ve 1876 Bimarhaneler Nizamnamesi". İçinde: Aydın AR, Keskin İ, Yelçe NZ, Ed. Engellilik Tarihi Yazıları (151-72). İstanbul: İstanbul Üniversitesi Yayınları.

9. Alkan, M. (2014). "Manisa'da Hafsa Sultan Dârüşşifası (Bîmarhanesi)". Turkish Studies. 9(10), 19-31.

10. Kılıç, R. (2013). "Osmanlı Devletinde Deliliğin Tarihi: Toptaşı Örneği”. Bilig. (67), 91-110.

11. Artvinli, F. (2019). "Osmanlı Devleti'nde Adlî Psikiyatri: Dr. Luigi Mongeri'nin Raporları, Tespitleri ve Bir Vaka Örneği”. Kebikeç: İnsan Bilimleri İçin Kaynak Araştırmaları Dergisi. (47), 233-268.

12. Toumarkine, N. (2013). "Adli Doktorlar, Ruh Doktorları ve Seyhler: Kummerau Olayı (1880) ve Bilirkișilik Meselesi". İçinde: Lévy A, Toumarkine N, ed. Osmanlı'da Asayiş, Suç ve Ceza. İstanbul: Tarih Vakfi Yurt Yayınları.

13. Amerikan Psikiyatri Birliği. (2014). DSM-5 Tanı Ölçütleri: Başvuru Elkitabı. Ankara: HYB Yayıncılık.

14. Turla, A. ve Böke, Ö. (2010). "Nedir Bu "Cinnet" Dedikleri?" Adli Bilimler Dergisi. 9 (1), 66-72.

15. Saint Martin, M.L. (1999). "Running Amok: A Modern Perspective on a Culture-Bound Syndrome". Primary Care Companion to The Journal of Clinical Psychiatry. 1 (3), 66-70.

16. Bingöl, S. (2015). "Osmanlı Devleti'nde Adli Olaylarda Kriminalistik Tekniklerin Uygulanması ve Kriminalistik Biliminin Doğuşu". İçinde: XVI Türk Tarih Kongresi, 2024 Eylül 2010, Ankara (1155-70). Ankara: Türk Tarih Kurumu Yayınları.

17. [Usman], M.O. (1911). Cinnet-i Meşâhir, 1: Giy dö Mopassan [Guy de Maupassant]. İstanbul: Matbaa-i Hayriye ve Sürekâs1.

18. [Basman], C.F. (1926). "Kanun-1 Cezamıza Göre Cinnet". Dârülfünun Hukuk Fakültesi. 4 (25), 229-35.

19. Köse, Ü. (2017). "İslâm Ceza Hukukunda Akıl Hastalarının Cana Karşı İşledikleri Suçlarda Cezai
Sorumlulukları". Kahramanmaraş Sütçü İmam Üniversitesi İlahiyat Fakültesi Dergisi. (29), 161-92.

20. Ahmet Cevdet Paşa. (1884). Mecelle-i Ahkâm-i Adliye. İstanbul: Matbaa-yı Osmaniye.

21. Dönmez, İ.K. (1993). “Cünûn”. İçinde: Türkiye Diyanet Vakfı İslâm Ansiklopedisi (125-9). Ankara: Türkiye Diyanet Vakfi Yayınevi.

22. Ekinci, E.B. (2008). Osmanlı Hukuku. İstanbul: Arı Sanat Yayınları.

23. Akyıldız, A. (2004). Osmanlı Bürokrasisi ve Modernleşme. İstanbul: İletişim Yayınları.

24. Bingöl, S. (2006). "XIX. Yüzyıl Osmanlı Mahkemelerinde Adli Tıp Uygulamaları". İçinde: XV Türk Tarih Kongresi, 11-15 Eylül 2006, Ankara (1351-64). Ankara: Türk Tarih Kurumu Yayınları.

25. Ceza Kanunâme-i Hümâyûn. (1335). Ceza Kanunâme-i Hümâyûn. Dersa'det: Matbaa-i Amire.

26. Ergin, O.N. (1912). Mecelle-i Umur-1 Belediye. C. 3. Dersa'det: Dersa'det Matbaası.

27. Terzioğlu, A. (1992). "Bîmâristan". İçinde: Türkiye Diyanet Vakfi İslâm Ansiklopedisi (163-78). Ankara: Türkiye Diyanet Vakfi Yayınevi.

28. Uludağ, O.Ş. (2010). Osmanlılar Devrinde Türk Hekimliği. Ankara: Türk Tarih Kurumu Basımevi.

29. Yıldırım, N. (2014). "Dârüşşifalardan Modern Hastanelere". İçinde: Sarı N, ed. 14 Yüzyıldan Cumhuriyet'e Hastalıklar ve Hastaneler Kurumlar (92149). İstanbul: Tarih Vakfi Yurt Yayınları.

30. 1289 Düstûr [Tertib 1], C. 3. Dersaadet: Matbaa-i Amire.

31. Şensoy, N. (1950). "Akli Maluliyetin İlmi Cepheden Tetkiki". Ankara Üniversitesi Hukuk Fakültesi Dergisi. 7 (1-2), 160-97.

32. Bahaddin, Ș. (1327). Tıp Kanunu Dersleri: Mevt ve Mevt Anları. İstanbul: Şurâ-yı Ümmet Matba'ası.

33. Centel, N. (2001). "Cezanın Amacı ve Belirlenmesi". İçinde: Prof Dr Turhan Tufan Yüce'ye Armağan (337-72). İzmir: Dokuz Eylül Üniversitesi.

34. [Usman], M.O. (1884-1915). 1928. Tebâbet-i Ruhiye. C. 1. İstanbul: Kader Matba'ası.

35. Bingöl, S. (2007). “Tanzimat İlkeleri Ișığında Osmanlı'da Adli Tababete Dair Notlar". Tarih Araştırmaları Dergisi. 26 (42), 37-65.

36. Güller, A. (2015). 19.YY. Arşiv Belgelerine Göre Osmanlı Toplumunda İntiharlar. Ordu Üniversitesi Sosyal Bilimler Enstitüsü, Yüksek Lisans Tezi.

37. Ulutaşdemir, N. (2002). "Kadına Yönelik Şiddet”. Sağlık ve Toplum. 12 (4), 15-21.

38. Tevfik, T. (1327). Yeni Kanûn-1 Cezâ. Dersaadet: Sems Matbaasi.

39. 1289. Düstûr [Tertib 1]. C. 1. Matbaa-i Amire. 
40. T.C. Cumhurbaşkanlığı Devlet Arşivleri Başkanlığı Osmanlı Arşivi. (BOA) (Ek: Arşiv Belgeleri Dergi Yazım İlkeleri Kapsamında Azami 40 Kaynak Sayısını Aștığı
İcin Ekte Verilmistir. Numaralar 40 Numaralı Kaynakçaya 1-32 Numara Verilmek Suretiyle Gösterilmiştir).

EK

*T.C. Cumhurbaşkanlığı Devlet Arşivleri Başkanlığı Osmanlı Arşivi (BOA)

40.1.DH.MKT.( Dahiliye Mektubi Kalemi): 2681/86, $1326 / 1908$.

40.2. A.\}MKT(Mektûbi Kalemi Evrak1): 87/14, 1263[1847]; DH.EUM (Dahiliye Nezareti Kalemi Belgeleri). 2.Şb: 18/57, 1334 [1915].

40.3. MVL(Meclis-i Vala): 608/17, 1277[1831]; ZB.(Zabtiye Nezareti): 490/116, 1324 [1908].

40.4. BEO (Bab-1 Âli Evrak Odas1): 454/33997, 1312/1894

40.5. İ. ŞD.(İrade, Şûra-yı Devlet): 30/1453.

40.6. A.\}MKT.: 87/45, 1263/1847; ZB.: 399/ 59, 1324/1908; DH.UMVM: 95/51,1334/1916.

40.7. A.\}MKT.: 87/45, 1263/1847; MVL: 707/2, 1282/1865; DH.ŞFR (Dahiliye Şifre Kalemi).: 170/53, 1310/1894; ZB.: 447/76, 1310/1894, 448/64, 1312/1896; 452/47, 1324/1908; 490/124, 1324/1908; ZB.: 310/57, 1322/1906.

40.8. DH.UMVM (Dahiliye Nezareti, Umûr-1 Mahalliye ve Vilâyât Müdüriyeti): 95/9, 1329/1911; HH.İ.( Hazine-i Hassa İradeler): 238/9, 1329/1911; DH.İD.(Dahiliye İdare): 65/24, 1330/1912.

40.9. ZB.: 331/11, 1325/1909.

40.10. DH.MKT.: 2069/67, 1312/1898.

40.11. ZB.: 448/147, 1313/1897.

40.12. ZB.: 309/10, 1322/1906; ZB.: 312/5, 1324/ 1908; ZB.: 399/67, 1324/1908 .; ZB.: 445/42, 1320/1904; ZB.: 468/19, 1322/1906; DH.ID..: 65/24, 1330/1912; DH.MB..HPS.M.(Dahiliye Nezareti, Mebâni-i Emiriye, Hapishaneler, Müteferrik): 7/45, 1330/1912.

40.13. ZB.: 476/156, 1323/1907.

40.14. A. \}MKT.MVL.: 7/81, 1264/1848; ZB.: 488/10, $1324 / 1908$.
40.15. ZB.: 491/54, 1324/ 1908; DH.EUM.THR (Kalemi).: $39 / 21,1328 / 1910$.

40.16. DH.MKT.: 2088/103, 1315/1898; BEO: 1105/82828, $1315 / 1898$.

40.17. ZB.: 420/120, 1320/1904; A, H.EUM.2.Şb: 18/57, $1334 / 1916$

40.18. A.\}MKT.MVL.: 59/11, 1269/1852

40.19. MVL: 608/17, 1277/1860.

40.20. HR.TH.(Hariciye Tahrirat): 11/36, 1872.

40.21 ZB.: 444/13, 1319/1903

40.22. A.\}MKT.UM..: 496/39, 1278/1861; A.\}MKT.UM..: 570/70, 1278/1862.; MVL: 934/24, 1278/1861; MVL: 743/18, 1282/1866; MVL: 707/2, 1282/1865; TFR.I..KV... 11/1057, 1320/1903; ZB.: 407/118, 1319/1903; 631/15, $1321 / 1905$

40.23. . TFR.I..SL..: 192/19149, 1326/1908.

40.24. A. \}MKT.MVL.: 59/11, 1269/1852.

40.25. MVL: $1079 / 19,1284 / 1867$.

40.26. A.\}MKT.MVL.: 7/81, 1264/1848; A.\}MKT. UM.(Sadaret Umum Vilayet Evrakı): 200/79, 1271/1855.

40.27. DH.MKT.: 2681/86, 1326/1908.

40.28. DH.MKT.: 1655/107, 1307/1889.

40.29. DH.H.: 64/27, 1330/1912; ZB.: 490/124, 1324/1908; DH.EUM.KADL(Emniyet-i Umumiye Müdüriyeti Kısm-1 Adlî Kalemi): 5/4, 1329/1911.

40.30. MVL: 608/17, 1277/1860; DH.MKT.: 2088/103, 1315/1898; ZB.: 444/13, 1319/1903.

40.31. A.\}MKT.MVL.: 7/81, 1264/1848; A.\}MKT.UM..: 200/79, 1271/1855.

40.32. A. \}MKT.MVL.: 8/63, 1264/1848; 11/27, 1264/1848; ZB.: 444/13, 1319/1903. 